\title{
Formative Assessment as a Component of the Future English Teacher Training
}

\author{
Marina Viktorovna Klimenko ${ }^{1} \&$ Larisa Arkadyevna Sleptsova ${ }^{1}$ \\ ${ }^{1}$ Bryansk State University, Russia \\ Correspondence: Marina Viktorovna Klimenko, Bryansk State University, Bezhitskaya Street, 14, 241036 \\ Bryansk, Russia.
}

Received: January 9, 2015 Accepted: March 1, 2015 Online Published: July 28, 2015

doi:10.5539/ies.v8n8p157 URL: http://dx.doi.org/10.5539/ies.v8n8p157

\begin{abstract}
The article deals with the problem of the initial stage of the future English teacher training and forming basic professional teaching skills by means of the implementation of formative assessment methods into the process of studying. It reveals the urgent necessity of using a modern and reliable system of assessment as a sound foundation of a high quality education and the key role of formative assessment in the process of foreign language teaching and learning. The aim of the article is to reveal the idea of formative assessment methods introduced into the course of English Speech Practice not only as a means of the first-year students' language competence formation but also as a tool of their pre-service training. It is illustrated how a purely language task can be supplied with a pedagogic component to organize activities as much as possible imitating the atmosphere and surroundings of a classroom with students performing the roles of teachers and pupils. The results of the research presented in the article make it evident that introducing formative assessment into a university English class is multi-purpose: teachers can assess their students' level of language knowledge and adjust the teaching process, and students can use it in solving professionally oriented practical tasks and assessing their peers and themselves.
\end{abstract}

Keywords: formative assessment, pedagogic component, language competence, peer assessment, self-assessment

\section{Introduction}

\subsection{Modern Approach to Assessment}

Recent changes in the Russian system of higher education, the participation in the Bologna process, the transition to the two-level system of training lead to the necessity of updating not only the curriculum and the content of training programs, but also the introduction of qualitatively new approaches to the implementation of higher education. In higher school teaching practice new spheres of humanities knowledge and new teaching methods are used.

The recognition of a free and educated personality as a core value raises the question of the quality of education as an integral part of Russia's entry into the unified educational world community. At this point the problem of creating a modern reliable assessment system complying with the international standards will prevail.

The theoretical basis of the research is formed by the works of such scientists as Arkhangelsky S. I., Babansky Y. K., Bolotov V. A., Gorbatov D. S., Gutnick G. V., Davydova L. N., Denisova L. G., Kamenskaya L. V., Katchalov V. A., Korolev M. F., Milrud R. P., Nesterov A. V., Pavlova S. G., Pashkov V. A., Selezneva N. A., Stepanova T. A., Shabanov T. A., Yakovlev E. V., Bachman L., Benson P., Gardner R. C., Lantolf J., Lemov D., et al. The language training method also includes significant developments in the sphere of monitoring learning and cognitive activity of students (Bim I. L., Galskova N. D., Gez N. I., Zimnyaya I. A., Kitaygorodskaya G. A., Leontiev A. A., Minyar-Beloruchev R. K., Mirolubov A. A., Passov E. I., Skalkin V. L., Starkov A. P., Shatilov S. F., Little D., O'Malley M. A., Norris J., McDonough S. et al.). However, in the modern paradigm of scientific knowledge the anthropocentric approach to the conversation focuses on understanding the relations of the language and thinking, that makes it a starting point of the student's pedagogical process. The implementation of the pedagogical component into the process of future teachers' training has been carried out by many methodologists and educators (L. Shulman, S. Magnusson, J. S. Krajcik, H. Borko, I. L. Silberberg, W. Hüllen et 
al.). They made attempt to evaluate students' perceptions of teachers' pedagogical content knowledge (Criu \& Marian, 2014). In case of foreign language learning the student certainly becomes an active participant in the analysis of this process.

\subsection{Formative Assessment and Its Role in the Educational Process}

In modern language training methods the necessity of creating conditions for the development of creativity and cognitive abilities of the personality, its initiative and independence, the ability to cross-cultural communication, the formation of all types of language competences are proclaimed, that ultimately should lead to the education of a new generation specialist, competitive in the international labor market (Baluyan S. R., Bim I. L., Galskova N. D., Zimnyaya I. A., Koryakovtseva N. F., Leontiev A. A., Polyakov O. G., Safonova V. V., Solovova E. N., Benson P., Cotterall S., Mori Y., Nunan D., Sinclair B., Skehan P., Andersen H. L., Cozart S. M. et al.). In this regard the problem of monitoring the quality of foreign language teaching seems particularly vital.

Nowadays more and more teachers along with traditional assessment (test papers, credits, exams, etc.) use formative assessment, and (that is highly important, from our point of view) try to systematize and streamline these forms. In domestic and foreign scientific and methodological journals over the last few years a significant number of articles devoted to the description, classification and analysis of the practical use of formative assessment at different stages of foreign language training have been published (Matienko, 2009; Susanina, 2014; Cross, 1995; Pharm, 2011; Teachers' Guide to Assessment, 2011; Lamprianou \& Athanasou, 2009; Djihadi, 2010; Huerta-Macias, 2002; Wiliam, 2011; Shaaban, 2000; Stiggins, 2001; Moss \& Brookhart, 2009; Ghaith, 2002; Clarke, 2005; Goldin \& Katz, 2008). Teachers consider different aspects of formative assessment, particularities of its use, advantages and disadvantages in comparison with traditional assessment, provide the results of own experimental work with formative assessment in its various forms.

According to the document "Common European Framework of Reference for Languages", whose main goal is to present the assessment and teaching method, applicable to all European languages, formative assessment is defined as follows: "Formative assessment is an ongoing process of gathering information on the extent of learning, on strengths and weaknesses, which the teacher can feed back into their course planning and the actual feedback they give learners" (CEFR, 2001). As we can see, formative assessment is an ongoing process that includes teaching, learning and assessment. It allows teachers to make the necessary changes in the teaching process, and students-in the learning process. Typically, this form of assessment is used at primary and secondary teaching stages. Its main task is to promote the optimal personal development of each student, to provide the so-called feedback in teaching and learning, to create conditions for reflection over the progress of these processes.

\subsection{Evolutive Function of Assessment}

In this regard a relatively new concept of "formative assessment", which shifts the focus from the comparative assessment of students to the personal development assessment, is considered to be of great importance (Tognolini \& Stanley, 2011). In our opinion, it is formative assessment that gives the assessment process the evolutive function, as such assessment operates at the individual micro-level and provides the teacher with the information for immediate adjustment of the teaching process (Heritage \& Chang, 2012).

The assessment problem gains special importance in case of a future foreign language teacher training, as the student is to acquire the knowledge of a foreign language (in our case it is English) not only as a means of communication (English as a Foreign Language), but also as a means of professional activity (English for Specific Purposes-teaching). Certainly, the immediate work at the classroom language will be done within the framework of the subject "Foreign Language Teaching Methods", but it is obvious that this work is impossible without the basic preparatory training of students within the framework of the subject "English Speech Practice". It would be impossible to undertake an internship at school, if the student is not trained to analyze the correctness of another person's speech and conduct self-assessment. So it could be recommended to provide students with corresponding opportunities to learn. It is recognized that the quality of future teachers' activities during an internship at school depends upon the outcomes of teacher education (König \& Blömeke, 2012).

The aim of the present article is to show the way formative assessment can be used when working with first-year students of the Faculty of Foreign Languages (the major is "Pedagogical Education") at the stage of taking the introductory course not only as a means of linguistic competence formation, but also as a means of pre-service training.

\section{Methods}

The methodological basis of the present study is the fundamental provisions of the person as a subject of 
learning and self-development, theories of personal-pragmatic and person-centered approaches, control theories in foreign language learning.

As a part of the study the following methods have been used: the analysis of pedagogical and methodological literature, the method of content-related generalization, hypothetical modeling, statistical information processing.

\subsection{Identification of the Level of Students' Language Competence}

At the beginning of the study it was necessary to establish the students' level of language knowledge at the beginning of the academic year. It was expected that the obtained data would help to improve the forms and methods of assessment of the students' work in studying the first section of the subject "English Speech Practice"-the introductory course.

Thus, at the first lesson the students were asked to answer a series of questions in order to form an overall picture of the group members. 33 students of three study groups took part in this survey. They were offered to fill in the following questionnaire:

\begin{tabular}{|c|c|c|c|}
\hline \multicolumn{4}{|l|}{ 1. Name } \\
\hline \multicolumn{4}{|l|}{ 2. Surname } \\
\hline 3. Secondary educational establishment finished & School $\square$ & Lyceum $\square$ & Gymnasium $\square$ \\
\hline \multicolumn{4}{|c|}{ 4. Amount of hours of English classes at school per week (in the 11th form) } \\
\hline 4. Grade in English at school & Excellent $\square$ & Good $\square$ & Satisfactory $\square$ \\
\hline 5. Total score in Final State Exam (English) & $20-50 \square$ & $51-75 \square$ & $76-100 \square$ \\
\hline
\end{tabular}

After processing the obtained data the generalized figures in terms of percentage points are as follows:

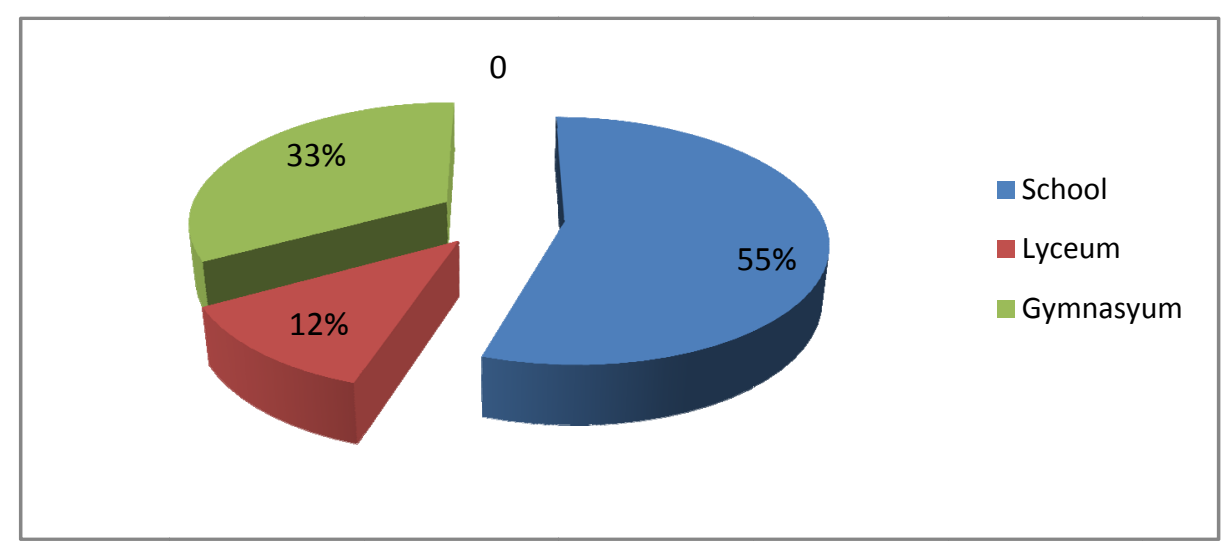

Figure 1. Secondary educational establishment finished

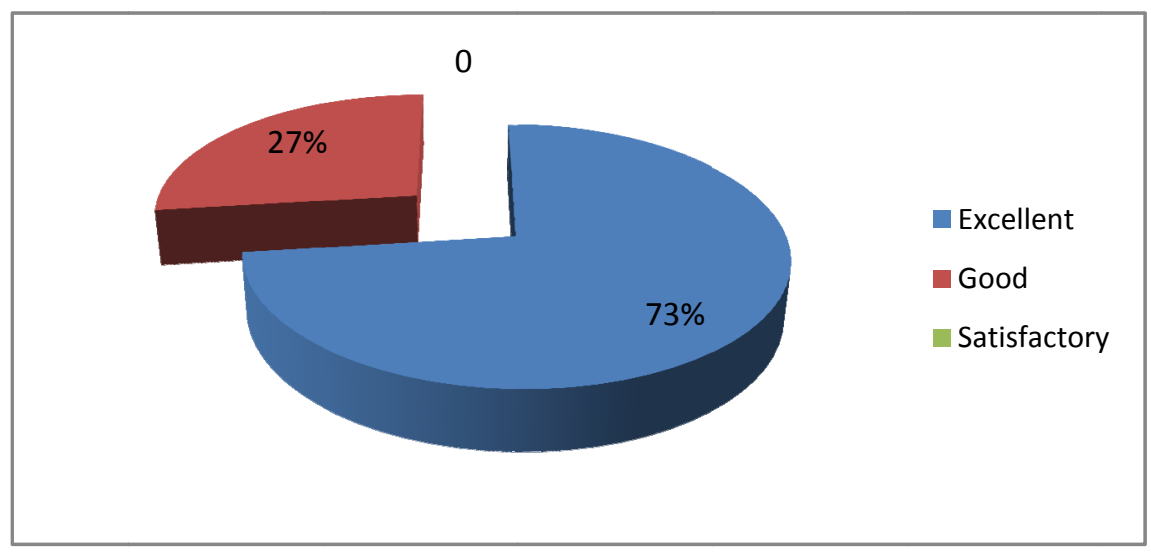

Figure 2. Grade in English at school 


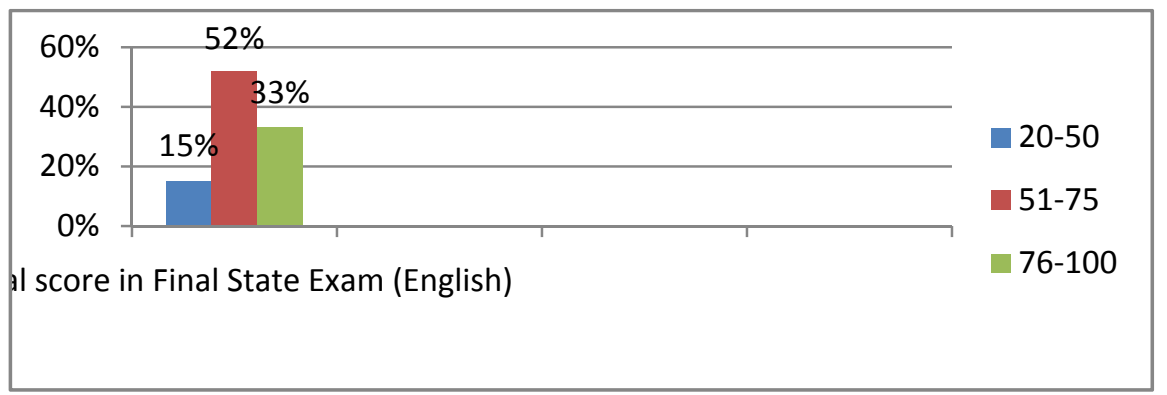

Figure 3. Total score in Final State Exam (English)

As we can see, most of the students who participated in the survey (55\%), finished secondary school. In the 11th form they had 3 (three) English lessons per week, that is considered an average indicator. A few students (12\%) are graduates of lyceums, one-third of students $(33 \%)$ are graduates of gymnasia, where the number of English lessons depended on the teaching profile and the availability of extracurricular activities $(4,6$ or even 8 hours per week). However, the proportion of students who had English classes more often than the other students, amounted only to $12 \%$.

The total score in Final State Exam (English) indicates the average and high level of language knowledge: more than half of the students (52\%) scored in the range from 51 to 75 points out of 100 possible ones (good average score), $33 \%$ had the highest scores in the range from 76 to 100 , and only $15 \%$ of all the respondents had low scores (20-50 out of 100 possible ones).

Thus, all the students had a sufficient level of language competence in order to begin learning the program of the subject "English Speech Practice."

\subsection{Identification of the Level of Language and Common Learning Skills at the Beginning of the Introductory Course}

In order to identify the gaps in the students' language knowledge and difficulties in applying the English knowledge they gained during the course of secondary school in the study of the introductory course and, accordingly, the subsequent development of tasks for elimination of the identified difficulties and the organization of formative assessment of the students' achievement level, we developed a questionnaire consisting of 12 questions. The questions were formulated in the native language so that students of all training levels could give clear and precise answers.

\begin{tabular}{|l|l|l|l|l|}
\hline At the beginning of the introductory-corrective course I could: & Always & Sometimes & Seldom & Never \\
\hline 1. understand the teacher speaking English & & & & \\
\hline 2. understand the explanation of the teacher in Russian & & & & \\
\hline 3. understand the explanation of the teacher in English & & & & \\
\hline $\begin{array}{l}\text { 4. follow the teacher's instructions without asking to repeat and } \\
\text { further explanation }\end{array}$ & & & & \\
\hline 5. ask the teacher to repeat the instruction in English & & & & \\
\hline 6. work in pairs (groups), ask the partner questions & & & & \\
\hline $\begin{array}{l}\text { 7. feel comfortable at the blackboard or when answering in front of } \\
\text { the group }\end{array}$ & & & & \\
\hline 8. understand and remember rules studied & & & & \\
\hline 9. answer the teacher's questions using the material studied & & & & \\
\hline 10. hear and imitate English sounds and their clusters correctly & & & & \\
\hline $\begin{array}{l}\text { 11. understand the graphical layout of the intonation, pronounce the } \\
\text { sentences in accordance with it }\end{array}$ & & & & \\
\hline 12. write down basic lexical units correctly & & & & \\
\hline
\end{tabular}




\subsection{Pedagogical Component of Traditional Linguistic Tasks}

Taking into account the detected difficulties of diverse nature, we have attempted to find the most effective techniques and methods of formative assessment of the students' work at the lessons in order to eliminate such difficulties and increase the overall interest of the students and their performance. It should be emphasized that in choosing the methods of formative assessment and attempting to gradually and systemically introduce these methods into the teaching process within the framework of the introductory course we tried to take into account the specific character of training areas-namely, the pedagogical component as the basis for pre-service training.

Thus, in order to help students overcome the fear of answering at the blackboard and lack of self-confidence in the performance of tasks in front of the group, on the one hand, and for the formation of the basis for communication with students as a teacher, on the other hand, we use professionally-oriented role plays (or fragments of these plays) on the material of the basic textbook of the introductory course. At the same time the students could use classroom expressions provided by the teacher as a base for the answer.

When organizing the fragment of the role plays in the "teacher-class" format the students were asked to act out a variety of situations based on the following expressions:

1) In turns. In turn, starting with Nick. Take it in turns, starting here. One at a time, please. One by one.

2) Who's going to start? Who's first? Who wants to start/begin?

3) Your turn. It's your turn (to read), Tim. Now you, Anna. You're next. Go ahead, Dasha.

4) Who hasn't had a turn? Anybody (still) not had a turn? Anybody else? Who else is there? Who's left?

Interaction situations within the framework of this fragment could be very diverse:

- Asking to read words or sentences in turn,

- Repeating after the teacher in chorus, then in turns,

- Giving individual tasks and asking the results.

For example, the tasks of the basic textbook such as "Read aloud" or "Read the following special questions. Concentrate on the intonation" (Practical English Course, 2012, pp. 58-59) were easily converted into the tasks of the following type:"Helen, work with the group. Ask the students to read the words from Exercise II aloud"; "Jane, do a bit of micro-teaching, please. Ask the group to read the following special questions and concentrate on the intonation. Please, don't forget your classroom English". The tasks of this type allow the teacher to assess the phonetic aspect of the student's speech and his/her ability to interact with the group.

\subsection{Some Forms of the Development of Peer Assessment and Self-Assessment}

For the development and assessment of students' ability to act in various roles in the learning process (the roles of an observer, organizer, performer, speaker, etc.) and correctly perform the sequence of actions and speech acts in accordance with the designated role, Misconception Check tasks were used for working in groups with one student acting as a teacher, organizing the activity of the class, one student acting as an observer to follow the accuracy of carrying out the task and one student acting as a judge, assessing the correctness of the work (peer assessment).

Let us provide an example for organization of the tasks of this type:

Work with the group. They'll have 3 minutes to look through the task, analyze the phonetic phenomena and find one odd in each chain, explain their choice:

1) in the, at that, cat that, tree, it's the

2) black cat, hot pot, get that, pink peon, stock broker

The technique "Traffic Lights" is an effective and at the same time quite simple method of formative assessment of the students' level of mastering the material given (Jenkins \& Krueger, 2012). Students are to prepare circles of three colors (red, yellow, green) and pencils of the corresponding colors. The teacher states the meanings of the colors and the students write them down:

- $\quad$ green-feel confident, understand;

- yellow-still unsure, don't quite understand;

- $\quad$ red-not confident, don't understand anything.

This form of assessment can be used in different ways: 
1) At the end of the lesson, if at the beginning of the lesson the teacher briefly formulates and writes on the blackboard 2-3 goals in English. After carrying out all the tasks aimed at achieving these goals, each student shows to which extent the goals have been achieved. For example:

a) To learn how to intone sentences pronounced with Low Rise;

b) To revise how to intone sentences pronounced with Low Fall;

c) To make micro dialogues with low rising and low falling nuclear tones.

2) While making intermediate or final tests of the introductory course. In this situation, the technique "Traffic Lights" is offered to students to assess their knowledge of the material studied and to make tasks on its basis. Thus, "Traffic Lights" helps identify knowledge gaps and compose test tasks most effectively in order to eliminate these gaps. For example:

Mark the given questions with red (Not confident, don't understand anything), yellow (Still unsure, don't quite understand) or green (Feel confident, understand):

I. Phonetic phenomena, find, explain:

1) Loss of plosion;

2) Loss of aspiration;

3) Assimilation;

4) Nasal plosion;

5) Lateral plosion.

II. Transcribe the sentence.

III. Mark the intonation of the sentence.

2.5 Identification of the Level of Language and Common Learning Skills upon Completion of the Introductory Course

Upon completion of the introductory-corrective course along with the traditional lexical and grammatical tests in order to reveal and assess in quantitative terms the students' level of acquisition of the educational material, we have conducted another survey that allowed to reveal the changes in students' attitude to different aspects of the training activities and the self-assessment of his/her achievements and the achievements of the other students of the group. The questionnaire included the following:

\begin{tabular}{|l|l|l|l|l|}
\hline Upon completion of the introductory course I can: & Always & Sometimes & Seldom & Never \\
\hline 1. understand the teacher speaking English & & & & \\
\hline 2. understand the explanation of the teacher in English & & & & \\
\hline $\begin{array}{l}\text { 3. follow the teacher's instructions without asking to repeat and } \\
\text { further explanation }\end{array}$ & & & & \\
\hline 4. ask the teacher to repeat the instruction in English & & & & \\
\hline 5. work in pairs (group), ask questions to the partner & & & & \\
\hline $\begin{array}{l}\text { 6. feel comfortable at the blackboard or when answering in front of } \\
\text { the group }\end{array}$ & & & & \\
\hline 7. understand and remember the rules learned & & & & \\
\hline $\begin{array}{l}\text { 8. participate in the discussion of the proposed issues, proving my } \\
\text { point of view with the material studied }\end{array}$ & & & & \\
\hline 9. pronounce English sounds and their clusters correctly & & & & \\
\hline 10. represent the intonation patterns graphically & & & & \\
\hline 11. perform the phonetic analysis of sentences & & & & \\
\hline 12. write down learned lexical units correctly & & & \\
\hline 13. act out dialogues in front of the group & & & \\
\hline
\end{tabular}




\begin{tabular}{|l|l|l|l|l|}
\hline $\begin{array}{l}\text { 14. compose mini-dialogues with the partner and represent them to } \\
\text { the group }\end{array}$ & & & & \\
\hline 15. notice mistakes of the other students & & & & \\
\hline 16. correct mistakes of the other students & & & & \\
\hline
\end{tabular}

\section{Results Obtained}

\subsection{Language and Common Learning Skills at the Beginning of the Introductory-Corrective Course}

The analysis of the students' responses at the beginning of the introductory course revealed the most difficult aspects in learning the subject, namely:

1) Asking the teacher to repeat the information in the foreign language appeared the greatest difficulty for the students (33\% of the students could do it sometimes, 33\%-seldom, $9 \%-$ never);

2) Answering at the blackboard and performing the tasks in front of the group brought emotional discomfort for a large number of students ( $42 \%$ of the students sometimes felt comfortable at the blackboard, $27 \%$-rarely, $3 \%$-never, and only $27 \%$ of the respondents always felt uncomfortable in such cases);

3) Correct imitation of English sounds and their clusters appeared a special difficulty for many students. That is sooner related to the practical, rather than to the emotional side of the problem $(39 \%$ of the students sometimes could do this, $18 \%$-rarely, $3 \%$-never);

4) The fact that many students had difficulties in understanding the graphic image of the intonation and pronouncing sentences in accordance with it appeared important for adjusting and improving techniques and methods of working with tasks of the introductory course (64\% of the students sometimes managed to perform the task, $24 \%$-rarely, $3 \%$-never, only $9 \%$ of the students could always do it);

5) Finally, even the basic skill of the correct spelling of the lexical units forming the basis of further successful learning of lexical topics within the framework of the subject studied presented some difficulties.

\subsection{Language and Common Learning Skills upon Completion of the Introductory Course}

Comparison of the results of the two surveys shows that as compared to the beginning of the introductory course the number of students who assess themselves positively in many aspects has significantly increased:

- $\quad 45 \%$ of the respondents can always pronounce English sounds correctly, present the intonation patterns graphically, perform the phonetic analysis of sentences (such an answer to this question reflects the students' self-assessment);

- the majority of the respondents (85\%) answered "always" and thus assessed their ability to participate in the discussion of the proposed issues proving their point of view with the material studied; to act out dialogues in front of the group; to make up mini-dialogues with partners and represent them to the group; to feel comfortable at the blackboard, answering in front of the group as permanent, and this indicates the emotional emancipation, lack of restraint, willingness to display own learning abilities and creativity when working with the material studied. These changes are clearly seen when comparing the answers to these questions with the answers to similar questions, which the students were asked at the beginning of the introductory course (the questions about the ability to work in pairs group, ask their partners questions, feel comfortable answering at the blackboard) and to which the majority of students responded "sometimes," "seldom" or even "never".

However, the answers "seldom" and "never" prevailed when students responded to the question about the ability to notice and correct other students' mistakes, which indicates the underdeveloped ability of the assessment of other students on the basis of the material studied.

\section{Discussion}

Our task was to use formative assessment methods not only in order to create the most comfortable emotional conditions for successful implementation of students' learning activities, but also at the same time attempt to bring these conditions to the situation of the real learning process, the main participants of which are teachers and secondary-school pupils-the situation that students should face during their teaching practice and future professional activities.

This approach to organizing students' speech activities at the lessons constitutes a complex means of formative assessment which enables: 
- The teacher to assess the students' level of language proficiency, the level of acquisition of rules and the ability to use them when performing the tasks;

- The students to assess their groupmates;

- The student to assess him/herself.

The results of the analysis of the conducted surveys indicate that at the following stages of learning the subject it is necessary to pay more attention to techniques and methods aimed at developing the students' peer assessment.

Thus, the organization of students' learning activities in the study of the subject "English Speech Practice" appears to be a promising direction of the further work based on such work forms which could promote the practical use of the material studied along with using the pedagogical component as an integral part of future professional activity (extended brainstorming, gapping, grids galore, scenarios and role plays) and the implementation of various forms and methods of formative assessment as a whole and in their variations on this basis.

\section{Conclusion}

It can be concluded that the introductory course of the subject "English Speech Practice" with the use of the techniques and methods of formative assessment of students appeared to be our base platform, the so-called "starting" point. This course allowed us to identify existing difficulties of the students both in terms of acquisition of language material, and in terms of overcoming barriers in communication with the teacher, face to face with the group, within the group when performing training tasks, with a partner in solving communication tasks in a foreign language. The analysis of the detected difficulties allows to effectively eliminate them on the basis of formative assessment.

In this regard the introductory course can be viewed as a "start" for the subsequent formation of the model of the future foreign language teacher considered as a set of professional and personal qualities, the high language level and the ability to use it in the situations of professional communication by means of formative assessment of the students. The form of assessment at each successive stage of the work upon the training program of the subject "English Speech Practice" will vary from the teacher's formative assessment of students, through peer assessment to self-assessment and, accordingly, to the possibility to improve one's own learning and future professional activities as an indicator of the high language level and language proficiency.

\section{References}

Arakin, V. et al. (2012). English Practical course. For the first-year students: the manual for university students (Edited by Arakin, V.D. $6^{\text {th }}$ revised and corrected edition). Moscow: Humanities Publishing Center VLADOS.

Clarke, S. (2005). Formative Assessment in the secondary classroom. London: Hodder \& Stoughton.

Criu, R., \& Marian, A. (2014). The Influence of Students' Perception of Pedagogical Content Knowledge on Self-efficacy in Self-regulating Learning in Training of Future Teachers. http://dx.doi.org/10.1016/j.sbspro.2014.07.596

Cross, L. (1995). Grading students. Practical Assessment, Research and Evaluation, 4(8), 1-4.

Djihadi, A. (2010). The Assessment in English Language Teaching: From Theory to Practice. Retrieved November 5, 2014, from http://agustinadjihadi.blogspot.ru/2010/07/assessment-in-english-languageteaching.html.

Ghaith, G. (2002). Using Cooperative Learning to Facilitate Alternative Assessment. Retrieved December 17, 2014, from http://www.academia.edu/6546143/Using_Cooperative_Learning_to_Facilitate_Alternative_A_ ssessment

Goldin, C., \& Katz, L. (2008). The race between education and technology. Cambridge MA: Harvard University Press.

Heritage, M., \& Chang, S. (2012, August). Teacher Use of Formative Assessment Data for English Language Learners. National Center for Research on Evaluation, Standards, \& Student Testing. P.2. Retrieved November 6, 2014, from https://www.cse.ucla.edu/products/states_schools/ELL_Symposium_FINAL.pdf

Huerta-Macias, A. (2002). Alternative assessment: Responses to commonly asked questions. Methodology in Language Teaching: An Anthology of Current Practice. New York.

Jenkins, S., \& Krueger, K. (2012, February 22). Differentiation with Embedded Assessment: Assessment that 
Shapes Instruction and Learning. Differentiation in the Classroom, Teacher Preparation Initiative at SCSU, New Teacher Meeting. Retrieved November 10, 2014, from https://www.stcloudstate.edu/tpi/teachersupport /documents/FormativeAssessment.pdf

König, J., \& Blömeke, S. (2012). Future teachers' general pedagogical knowledge from a comparative perspective: Does school experience matter? http://dx.doi.org/10.1007/s11858-012-0394-1

Lamprianou, I., \& Athanasou, J. (2009). A Teacher's Guide to Educational Assessment (Revised Edition). Rotterdam: Sense Publishers. Retrieved November 14, 2014, from https://www.sensepublishers.com/media/ 29-a-teachers-guide-to-educational-assessment.pdf.

Matienko, A. (2009). Formative Control in Teaching a Foreign Language as a Means of Improving the Quality of Linguistic Education. Research Library of Dissertations and Abstracts disserCat. Retrieved December 17, 2014, from http://www.dissercat.com/content/alternativnyi-kontrol-v-obuchenii-inostrannomu-yazyku-kaksredstvo-povysheniya-kachestva-yaz\#ixzz3IBaSJ9IZ.

Moss, C., \& Brookhart, S. (2009). Advancing Formative Assessment in Every Classroom: A Guide for Instructional Leaders. Retrieved December 17, 2014, from http://www.ascd.org/publications/books/109031. aspx

Pharm, L. (2011). Formative Assessment in Primary English Classrooms in Vietnam. New Directions: Assessment and Evaluation. A collection of papers. Edited by Dr. Philip Powell-Davies. British Council.

Shaaban, K. (2000). Assessment of Young Learners' Achievement in ESL Classes in the Lebanon. Language, Culture and Curriculum, 3(13), 306-317. http://dx.doi.org/10.1080/07908310008666606

Stiggins, R. (2001). Student-Involved Classroom Assessment (3rd ed.). New York, Upper Saddle River: Prentice hall.

Susanina, E. (2014). Formative assessment of the students' achievements and activities at English lessons. Retrieved November 5, 2014, from http://festival.1september.ru/articles/416801/

Teachers' Guide to Assessment. (2011, June). The Cross Sectorial Assessment Working Party. Retrieved November 6, 2014, from http://www.det.act.gov.au/_data/assets/pdf_file/0011/297182/Teachers_Guide_to _Assessment_Web.pdf.

Tognolini, J., \& Stanley, G. (2011). A Standards Perspective on the Relationship between Formative and Summative Assessment. New Directions: Assessment and Evaluation. A collection of papers. Edited by Dr Philip Powell-Davies. British Council.

Wiliam, D. (2011). Embedded Formative Assessment. Solution Tree Press.

\section{Copyrights}

Copyright for this article is retained by the author(s), with first publication rights granted to the journal.

This is an open-access article distributed under the terms and conditions of the Creative Commons Attribution license (http://creativecommons.org/licenses/by/3.0/). 